\title{
Risk Areas for Influenza A(H5) Environmental Contamination in Live Bird Markets, Dhaka, Bangladesh
}

\author{
Shovon Chakma, Muzaffar G. Osmani, Holy Akwar, Zakiul Hasan, Tanzinah Nasrin, \\ Md Rezaul Karim, Mohammed Abdus Samad, Mohammad Giasuddin, Peter Sly, \\ Zahir Islam, Nitish Chandra Debnath, Eric Brum, Ricardo Soares Magalhães
}

We evaluated the presence of influenza $\mathrm{A}(\mathrm{H} 5)$ virus environmental contamination in live bird markets (LBMs) in Dhaka, Bangladesh. By using Bernoulli generalized linear models and multinomial logistic regression models, we quantified LBM-level factors associated with market work zone-specific influenza $\mathrm{A}(\mathrm{H} 5)$ virus contamination patterns. Results showed higher environmental contamination in LBMs that have wholesale and retail operations compared with retail-only markets (relative risk 0.69 , $95 \% 0.51-0.93 ; p=0.012$ ) and in March compared with January (relative risk 2.07, 95\% Cl 1.44-2.96; $p<0.001$ ). Influenza $\mathrm{A}(\mathrm{H} 5)$ environmental contamination remains a public health problem in most LBMs in Dhaka, which underscores the need to implement enhanced biosecurity interventions in LBMs in Bangladesh.

\section{T ive bird markets (LBMs) have long been identified Las major sites for the maintenance, transmission, amplification, and dissemination of influenza A(H5) virus $(1,2)$. Studies in the United States, China, Indo- nesia, and Vietnam have shown that LBMs can pose a public health risk for zoonotic spill-over to humans through environmental contamination (2-8). In Ban- gladesh, the first evidence of zoonotic transmission of influenza A(H5) virus emerged in 2012; LBMs in Dha- ka were considered the main source of exposure for all 3 human cases reported $(9,10)$. The relatively low level of influenza $\mathrm{A}(\mathrm{H} 5)$ endemicity found in studies}

Author affiliations: Emergency Centre for Transboundary Animal Diseases, Food and Agriculture Organization of the United Nations, Dhaka, Bangladesh (S. Chakma, H. Akwar, Z. Hasan, T. Nasrin, N.C. Debnath, E. Brum); The University of Queensland, Brisbane, Queensland, Australia (S. Chakma, P. Sly, Z. Islam, R. Soares Magalhães); Department of Livestock Services, Dhaka (M.G. Osmani); Bangladesh Livestock Research Institute, Savar, Bangladesh (M. Rezaul Karim, M. Abdus Samad, M. Giasuddin)

DOI: https://doi.org/10.3201/eid2709.204447 conducted in LBMs in Bangladesh since 2012 (e.g., $\leq 10 \%$ prevalence at live bird sampling level) (11-13) have contributed to a false sense of security regarding contamination risk. Indeed, since 2013, several influenza $\mathrm{A}(\mathrm{H} 5)$ outbreaks in poultry (9 outbreaks), wild birds (5 outbreaks), and humans (2 outbreaks) have occurred in Bangladesh (14,15). During March 2007December 2020, Bangladesh reported 556 outbreaks of influenza $\mathrm{A}(\mathrm{H} 5)$ virus in poultry (14) and 8 cases in humans (15).

Environmental sampling in LBMs for the purposes of avian influenza virus surveillance was first introduced in the United States in 1986 (16). A recent study evaluated the effectiveness of environmental sampling for influenza A surveillance and described multiple sampling sites in an LBM (17). Earlier studies from Bangladesh primarily focused on collecting samples from market environment sites (such as market floor, stall floor, slaughter area, waste bin, poultry cage, water, fecal material on or underneath the poultry cage, blood, and poultry offal) to understand the LBM environment status for influenza A $(11,12,18-25)$.

Few studies to date -1 in Indonesia and 3 in Guangdong, China-have performed simultaneous sampling in different LBM work zones, such as the poultry delivery, poultry holding, poultry slaughter, poultry sale, and waste disposal zones (26-29). These studies indicated that the poultry slaughter and sale zones were the 2 most contaminated LBM work zones for influenza A(H5N1) in Indonesia (27) and influenza A(H7N9), (H5), and (H9) in China $(26,28,29)$. To date, no studies have been performed in Bangladesh on influenza A environmental contamination within different LBM work zones. The results from China and Indonesia have provided additional justification to evaluate the influenza A surveillance program of 
the Food and Agriculture Organization of the United Nations (FAO) in Bangladesh. Given the costs of maintaining influenza surveillance programs, epidemiologic evidence on within-market risk areas for contamination would help fine-tune current surveillance approaches in Bangladesh.

Implementing biosecurity practices in LBMs reduces environmental contamination with influenza A (30). For example, weekly market closures ( $\geq 1$ day) and everyday cleaning and disinfecting interventions were reported to reduce market contamination with avian influenza virus (H7N2) in the United States and influenza (H7N9) and (H9N2) in China $(5,31,32)$. In Bangladesh, improved biosecurity practices at the market level have not effectively reduced environmental contamination for influenza $\mathrm{A}(\mathrm{H} 5)$ virus in Dhaka and Chittagong LBMs during 2012-2014 $(22,25)$. Since 2014 , no study has comprehensively reported the effect of market-level biosecurity practices on the probability of influenza $\mathrm{A}(\mathrm{H} 5)$ environmental contamination in Dhaka. Although the 2 administrative areas of the Dhaka metropolitan area (Dhaka North City Corporation [DNCC] and Dhaka South City Corporation [DSCC]) are known for their distinct demographic and urban features (33), no studies to date have investigated how biosecurity practices and influenza $\mathrm{A}(\mathrm{H} 5)$ contamination rates differ in relation to market-level characteristics of LBMs located in different parts of Dhaka. To inform the development of effective environmental sampling strategies for influenza surveillance in LBMs, our study sought to characterize the differences in the proportion of influenza $\mathrm{A}(\mathrm{H} 5)$ environmental contamination in markets in DNCC and DSCC, to identify and quantify market-level factors associated with the probability of influenza $\mathrm{A}(\mathrm{H} 5)$ contamination in specific work zones (i.e., arrival, slaughtering and processing, and consumer exposure or sales), and to identify and quantify market-level factors associated with work zone-specific contamination patterns within LBMs.

\section{Materials and Methods}

\section{Study Design for Influenza A(H5) Virus Surveillance in LBMs in Dhaka Metropolitan}

We focused our investigation on the Dhaka metropolitan area, which has the highest population density $(30,551$ residents $/ \mathrm{km}^{2}$ ) of all metropolitan areas in Bangladesh (34). We selected 104 LBMs within metropolitan Dhaka (Figure 1), which were part of the influenza surveillance initiative of the FAO and Department of Livestock Services (DLS) (Appendix, https://wwwnc.cdc.gov/EID/ article/27/9/20-4447-App1.pdf) (35). Sampling targeted the months of January-March, which are known for a higher level of circulation of influenza $\mathrm{A}(\mathrm{H} 5)$ virus in poultry in Bangladesh (36).

We used data on market-level characteristics collected during the Dhaka LBM census to quantify the association between influenza $\mathrm{A}(\mathrm{H} 5)$ environmental contamination in LBMs and within specific market work zones adjusted for market-level characteristics (Appendix). Three market work zones (poultry arrival $[\mathrm{A}]$, poultry slaughtering and processing [S], and consumer exposure or sales [E]) and environmental sites in each work zone were selected for sampling on the basis of the findings from Indrani et al. (Appendix) (27).

\section{Collection, Preservation, and Transportation of Environmental Samples}

Sample collectors from DLS, DNCC, and DSCC performed monthly collection of environmental samples from the selected LBMs. In a given visit, a pool of 6 samples were collected from each work zone using standard polyester-tipped swabs and stored separately in a $3 \mathrm{~mL}$ viral transport medium (Becton Dickinson, https://www.bd.com). Pooled samples were kept in ice boxes and transported to the DLS Central Disease Investigation Laboratory and Livestock Research Institute laboratory for temporary storage at $4^{\circ} \mathrm{C}$. All samples were then transported in ice boxes to the National Reference Laboratory for Avian Influenza at Bangladesh Livestock Research Institute (Savar, Dhaka) and stored at $-80^{\circ} \mathrm{C}$ before testing.

\section{Laboratory Testing}

We tested for influenza $\mathrm{A}(\mathrm{H} 5)$ virus 18 -swab pools from each selected market (i.e., 6 swabs/3 work zones) using real-time reverse transcription PCR (rRT-PCR). When an 18-swab pool of a market tested positive, further testing was carried out using rRTPCR to confirm influenza $\mathrm{A}(\mathrm{H} 5)$ virus in the 6-swab pool of a specific work zone (Figure 2). We used MagMAX viral RNA isolation kit and KingFisher mL Purification System extractor (ThermoFisher Scientific, https:/ / www.thermofisher.com) for RNA extraction. The rRT-PCR testing protocols followed the procedures recommended by the Australian Centre for Disease Preparedness quality assurance manual with influenza A(H5) primers (IVA D148 H5, IVA D149 H5, IVA D204f, and IVA D205r) and probes (IVA H5a and IVA D215P) produced at Australian Animal Health Laboratory and AgPath-ID One-Step RT-PCR Reagents (ThermoFisher Scientific). A pool sample was considered positive for influenza $\mathrm{A}(\mathrm{H} 5)$ if the cycle threshold value was $<40$ (37). 


\section{Data Analyses}

Our study included markets with information on both infection status and market-level characteristics $(\mathrm{n}=97)$ and those with information on market-level infection status only ( $\mathrm{n}=7)$. In our analyses, we considered 2 outcomes of interest: presence or absence of influenza $\mathrm{A}(\mathrm{H} 5)$ virus environmental contamination in specific work zones and LBM-level zone-specific influenza $\mathrm{A}(\mathrm{H} 5)$ environmental contamination patterns. Work zone-specific environmental contamination patterns were classified as negative if all 3 work zones tested negative; ASE-positive when all 3 work zones tested positive; $S$ only-positive when only the slaughtering and processing zone tested positive; SEor AS-positive when the slaughtering and processing zone and 1 other work zone (E or A) tested positive; and other when the market tested positive for A only, E only, or both A and E.

We summarized DNCC and DSCC market-level biosecurity characteristics by using descriptive statistical analyses. Market-level biosecurity characteristics considered in the investigation included market location, market type, species sold, number of vendors,

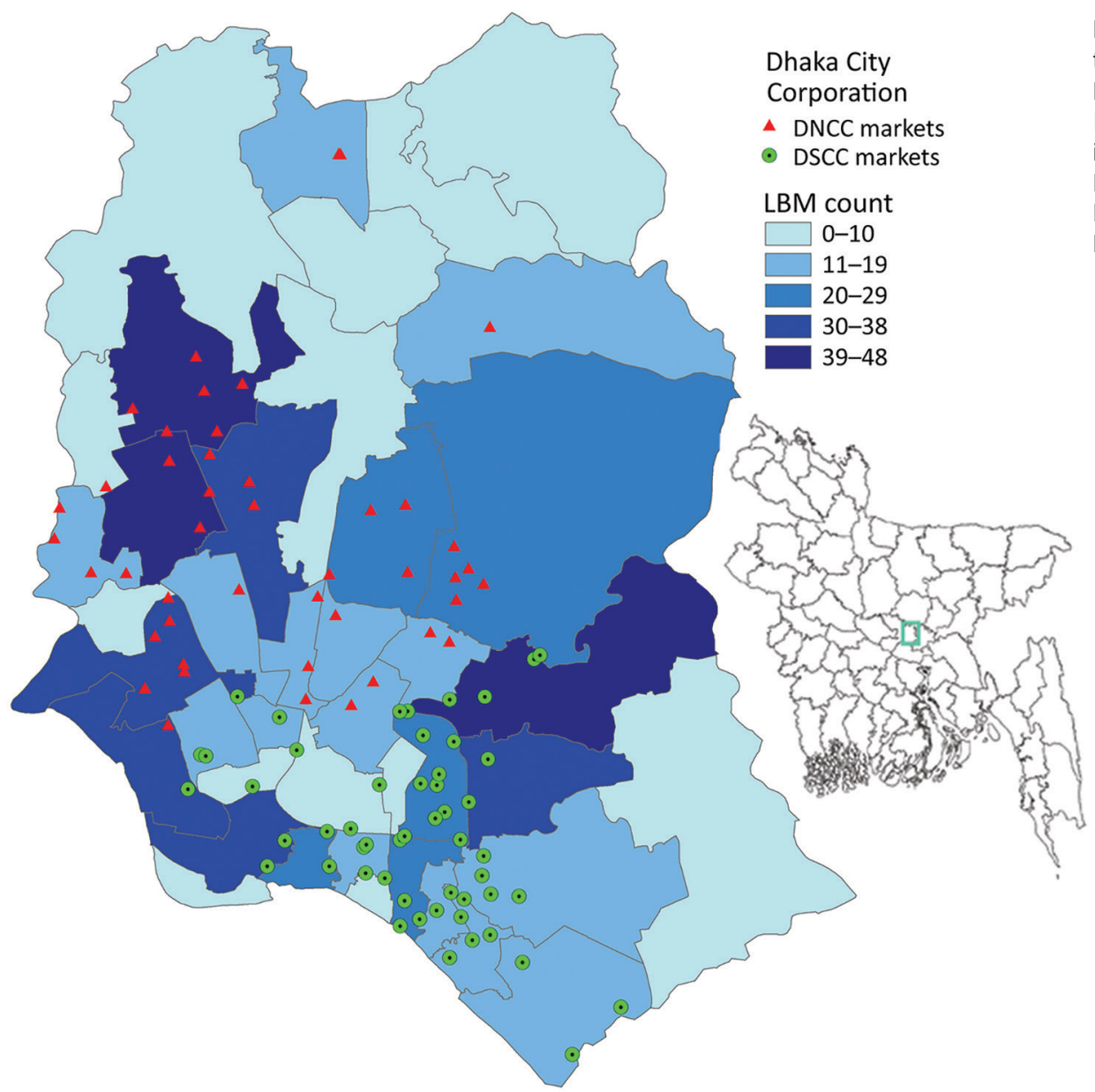

number of poultry species sold, dominant species (by comparing the poultry headcount), poultry headcount, electricity in the facility, presence of roof, running water in the facility, sale of poultry to other vendors, weekly market closure ( $\geq 1$ day), direct sale of poultry to consumers, sale of products other than poultry (i.e., fish, red meat, vegetables, groceries), daily cleaning protocol (at minimum with detergent), poultry slaughtering locations, and number of slaughtering facilities. We used a univariable Fisher exact test with a significance level of $p<0.05$ to identify differences in influenza $\mathrm{A}(\mathrm{H} 5)$ recovery by the geographic location of Dhaka markets. We then ran Bernoulli generalized linear models and multinomial logistic regression models to quantify risk factors associated with the probability of influenza $\mathrm{A}(\mathrm{H} 5)$ environmental contamination and work zone-specific contamination patterns (Appendix). The goodness-of-fit of the final multivariable model was assessed by Akaike information criterion (AIC), and the lowest AIC among all competing models was identified as the best fitting model in the study (38). We used Stata 15 (StataCorp LLC, https:/ / www. stata.com) for statistical analyses.

Figure 1. Locations of LBMs in the Dhaka metropolitan area, Bangladesh, January-March 2016. Inset map shows location of Dhaka in Bangladesh. DNCC, Dhaka North City Corporation; DSCC, Dhaka South City Corporation; LBM, live bird market. 


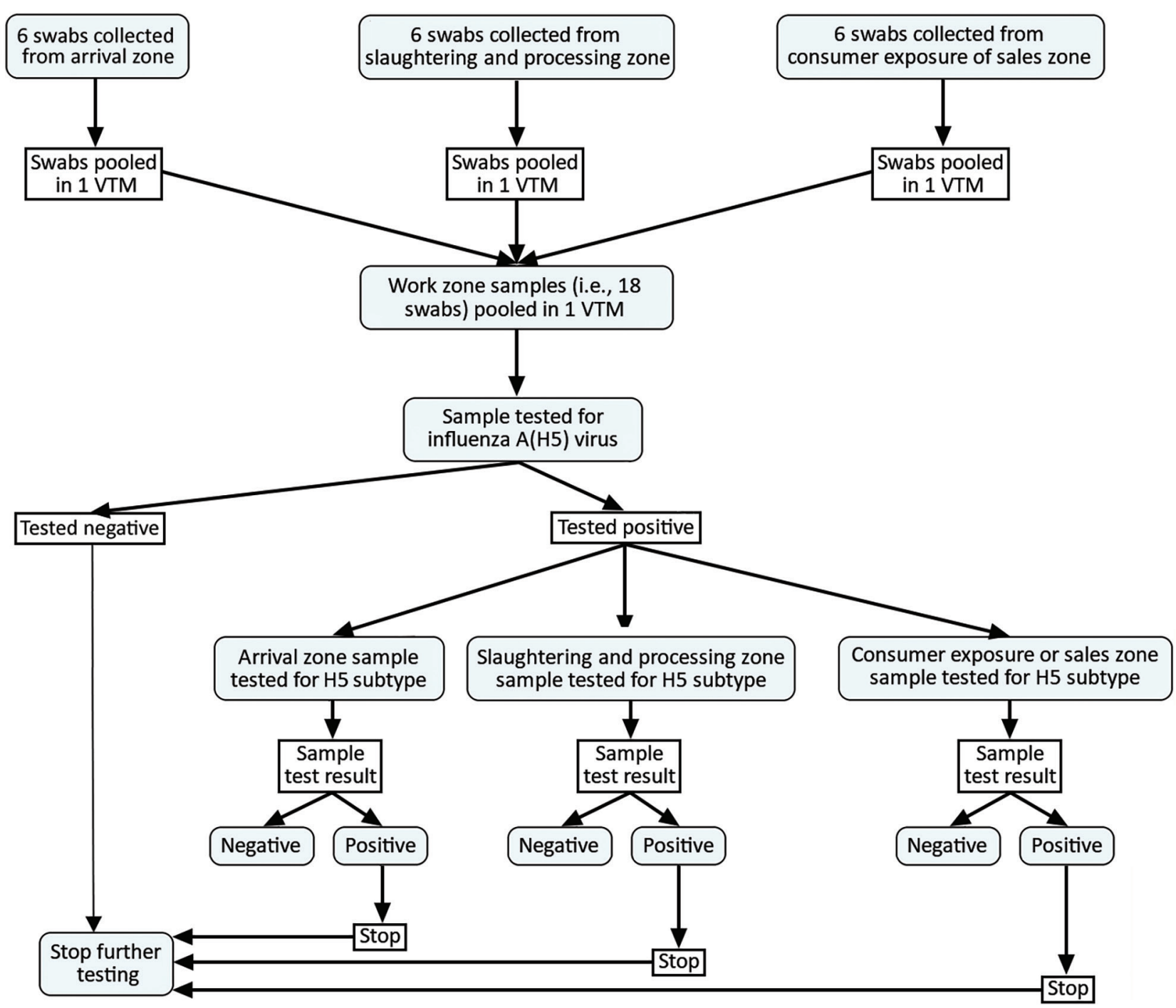

Figure 2. Sampling and laboratory testing protocol for influenza A(H5) in live bird markets, Dhaka, Bangladesh, January-March 2016. VTM, viral transport medium.

\section{Results}

\section{Characteristics of LBMs}

Of 104 enrolled LBMs, a total of 97 markets (52 from DSCC and 45 from DNCC) had complete questionnaire information on their biosecurity characteristics (Appendix Table 1). The retail type of LBM was predominant in DSCC $(84.62 \%, 45 / 52)$ and DNCC $(64.44 \%, 29 / 45)$ of Dhaka. Most markets in DSCC $(88.46 \%, 46 / 52)$ and DNCC $(97.78 \%, 44 / 45)$ sold multiple species of poultry. The broiler chicken was the main species at LBMs in DSCC $(69.23 \%, 36 / 52)$ and $\operatorname{DNCC}(80.00 \%, 36 / 45)$.

Market-level daily cleaning (at minimum with detergent) and weekly market closure ( $\geq 1$ day) practices varied among DNCC and DSCC markets. These 2 practices were reported to be more common in DSCC markets $(75.00 \%$ [39/52] for daily cleaning and $45.15 \%$ [24/52] for weekly closure) compared with DNCC markets (31.11\% [23/45] and 17.78\% [8/45]). Most markets reported slaughtering poultry at vendor stalls $(78.85 \%$ [41/52] in DSCC and $93.33 \%$ [42/45] in DNCC) (Appendix Table 1).

\section{Differences in the Proportion of Influenza A(H5) Virus Environmental Contamination and Market Characteristics}

Our analysis indicates that the proportion of influenza A(H5) virus environmental contamination was significantly higher in March than the previous 2 months 
$(p \leq 0.001)$ (Appendix Table 2). The trend of LBM work zone-specific influenza $\mathrm{A}(\mathrm{H} 5)$ environmental contamination was similar in March in DSCC and DNCC markets, and the highest level of environmental contamination was in the slaughtering and processing zone (Figure 3). Of all market-level characteristics, only 3 characteristics were found to be significantly associated with proportions of influenza $\mathrm{A}(\mathrm{H} 5)$ environmental contamination: market type $(p=0.036)$ and location of poultry slaughtering $(p=0.014)$ in DNCC markets and weekly market closure of $\geq 1$ day $(p=0.006)$ in DSCC markets (Appendix Table 2).

\section{Factors Associated with Influenza A(H5) Virus Environmental Contamination within LBMs}

\section{Factors Associated with the Probability of LBM Influenza A(H5) Environmental Contamination Risk}

We demonstrated by univariable analysis that the probability of influenza $\mathrm{A}(\mathrm{H} 5)$ environmental contamination was significantly higher in slaughtering and processing zones (relative risk [RR] 1.22, 95\% CI $1.01-1.49 ; p=0.041)$ than in market arrival zones. The probability of contamination was significantly higher in March (RR 1.90, 95\% CI 1.36-2.65; p $\leq 0.001$ ) than January (Table 1).

In the final multivariable analysis (model 2), after adjusting for market-level biosecurity factors, we demonstrated that the probability of influenza $\mathrm{A}(\mathrm{H} 5)$ environmental contamination remained 2-fold significantly higher in March than January (RR 2.07, 95\% CI 1.44-2.96; $\mathrm{p}<0.001)$. Our findings also demonstrated that slaughtering and processing zones had an increased risk for influenza $\mathrm{A}(\mathrm{H} 5)$ recovery compared to the arrival zone, but this effect was not statistically significant (RR 1.21, 95\% CI 0.99-1.49; $p=0.067$ ). In addition, the probability of influenza $\mathrm{A}(\mathrm{H} 5)$ environmental contamination was significantly associated with market type: retail markets were at lower risk than dual-purpose markets (RR 0.69, 95\% CI 0.510.93; $p=0.012)$ (Table 1). Model 2 presented a better fit to the data than model 1 (i.e., without adjusting for market-level biosecurity factors). The AIC of model 1 was 1020.6 and in model 2 was 932.9. Effect modification and confounding were not found among pairs of biologically plausible LBM predictor variables.

\section{Factors Associated with Work Zone-Specific Influenza A(H5)} Virus Environmental Contamination Patterns

Our univariable and multivariable model of the multinomial analysis showed a significant increased risk in all LBM work zone-specific influenza A(H5) environmental contamination patterns except "slaughtering and processing zone area only" in March (relative risk ratio $[R R R]>1$; null value not contained within 95\% CI) compared with January (Table 2, https:// wwwnc.cdc.gov/EID/article/27/9/20-4447-T2. htm). After multivariable adjustment, no marketlevel factors were significantly associated with work zone-specific influenza $\mathrm{A}(\mathrm{H} 5)$ virus environmental contamination patterns.

\section{Discussion}

Our analyses provide the most comprehensive account of the recovery of influenza A(H5) virus in specific LBM work zones over 3 months across a large sample of LBMs $(n=104)$ within the Dhaka metropolitan area of Bangladesh. This study overcomes many of the limitations seen in previous studies of LBMs in Dhaka in the context of within-market measurement of environmental contamination $(11,12,19,20,22,25)$.

Our descriptive results indicated vulnerabilities in LBMs in Dhaka associated with increased proportions of influenza A(H5) virus environmental contamination. Previous studies have shown that dual-purpose LBMs (i.e., markets conducting both wholesale and retail operations) in Dhaka were at higher risk for influenza A contamination (11). This previous finding suggests that markets in DNCC would be at greater risk for influenza $\mathrm{A}(\mathrm{H} 5)$ contamination. Our analyses confirmed this suggestion, demonstrating a larger proportion of influenza $\mathrm{A}(\mathrm{H} 5)$ recovery in dualpurpose DNCC markets than in retail-only markets. Poultry slaughtering has been consistently found to be a significant risk factor for LBM environmental contamination with influenza $\mathrm{A}(\mathrm{H} 5)$, and studies in Indonesia $(2,27)$ and Bangladesh (19) support this observation. Environmental contamination with influenza $\mathrm{A}(\mathrm{H} 5)$ was significantly higher in DNCC markets without slaughtering facilities than in those reporting poultry slaughtering. Market environmental contamination in the absence of slaughtering facilities could be linked to the sampling procedure, in which sample collectors were instructed to use their sense of perceived risk if suggested sampling sites were not present in the market and other sites had to be chosen. This limitation in the sampling procedure should be corrected in future studies. Biosecurity practices such as cleaning and market closures have been reported to reduce environmental contamination in LBMs and eliminate risk for human infection with influenza A (39). Our results indicate that DSCC markets would benefit from higher rates of closures; a higher proportion of influenza $\mathrm{A}(\mathrm{H} 5)$ contamination was found in DSCC markets that did not perform market closures. In 2017, China established the 
1110 policy, which involves daily cleaning, weekly disinfection, monthly closure, and no overnight stay of poultry (40). This approach has been successful at reducing the level of contamination within LBMs. This suggests that the implementation of a 1110-type policy in Dhaka's LBMs would strengthen LBM biosecurity, thereby reducing the level of influenza $\mathrm{A}(\mathrm{H} 5)$ contamination. Taken together, the observed differences in environmental contamination between markets in DSCC and DNCC can partly be explained by poultry slaughter and market management activities and less so by trader and poultry demographics.

Risk for influenza $\mathrm{A}(\mathrm{H} 5)$ infection in humans and poultry has been shown to be associated with movement of live poultry during national festive periods (41-43). In Bangladesh, demand for poultry products is influenced by traditional customs and rituals, including religious and cultural festivals (44-46). Our analysis found a 2-fold increase in the probability of environmental contamination in March compared with January, and market-level covariates did not modify this effect. Our analysis indicates the increased probability of influenza $\mathrm{A}(\mathrm{H} 5)$ environmental contamination in March in urban LBMs of Dhaka is likely related to the Bangla new year festival, which occurs in April and is linked to increased demand for poultry products in urban Dhaka LBMs.

We demonstrated that influenza A(H5) environmental contamination was positively associated with 2 market-level covariates: work zone (slaughtering and processing zone compared with arrival zone) and type of market (dual-purpose markets compared with retail-only markets). The higher probability of influenza $\mathrm{A}(\mathrm{H} 5)$ environmental contamination in the slaughtering and processing zone and in dualpurpose markets could be related to the challenge of maintaining adequate sanitation in LBMs with these characteristics. The risk for environmental contamination is known to be increased when slaughtering equipment is not frequently cleaned throughout the day using adequate disinfection protocols (47). Market attributes such as the presence of wholesalers in the market (11) and within-market trade of asymptomatic poultry between wholesalers and retailers (44) explain the higher levels of influenza A(H5) environmental contamination in dual-purpose markets compared with retail markets. Our analysis uncovered biosecurity characteristics that could partially explain these higher levels of influenza A(H5) environmental contamination. For example, dual-purpose markets have greater heterogeneity in poultry species

\begin{tabular}{|c|c|c|c|c|c|c|c|c|c|}
\hline \multirow[b]{2}{*}{ Risk factor } & \multicolumn{3}{|c|}{ Univariable analysis } & \multicolumn{3}{|c|}{ Multivariable model 1} & \multicolumn{3}{|c|}{ Multivariable model 2} \\
\hline & $\begin{array}{c}\mathrm{RR} \\
(95 \% \mathrm{Cl})\end{array}$ & $\mathrm{p}$ value & $\begin{array}{l}\text { Overall } \\
\mathrm{p} \text { value }\end{array}$ & $\begin{array}{c}\mathrm{RR} \\
(95 \% \mathrm{Cl})\end{array}$ & $\mathrm{p}$ value & $\begin{array}{l}\text { Overall } \\
\mathrm{p} \text { value }\end{array}$ & $\begin{array}{c}\mathrm{RR} \\
(95 \% \mathrm{Cl})\end{array}$ & $p$ value & $\begin{array}{l}\text { Overall } \\
\text { p value }\end{array}$ \\
\hline \multicolumn{10}{|c|}{ Market work zones of sample collection; reference: arrival } \\
\hline $\begin{array}{l}\text { Slaughtering and } \\
\text { processing }\end{array}$ & $\begin{array}{c}1.22 \\
(1.01-1.49)\end{array}$ & 0.041 & 0.110 & $\begin{array}{c}1.23 \\
(1.01-1.50)\end{array}$ & 0.040 & 0.103 & $\begin{array}{c}1.21 \\
(0.99-1.49)\end{array}$ & 0.067 & 0.180 \\
\hline $\begin{array}{l}\text { Consumer exposure } \\
\text { or sales }\end{array}$ & $\begin{array}{c}1.05 \\
(0.84-1.31)\end{array}$ & 0.647 & & $\begin{array}{c}1.05 \\
(0.84-1.32)\end{array}$ & 0.655 & & $\begin{array}{c}1.09 \\
(0.86-1.37)\end{array}$ & 0.487 & \\
\hline \multicolumn{10}{|c|}{ Month of sample collection; reference: January } \\
\hline February & $\begin{array}{c}1.24 \\
(0.87-1.77)\end{array}$ & 0.233 & $<0.001$ & $\begin{array}{c}1.24 \\
(0.87-1.76)\end{array}$ & 0.239 & $<0.001$ & $\begin{array}{c}1.33 \\
(0.91-1.94)\end{array}$ & 0.138 & $<0.001$ \\
\hline March & $\begin{array}{c}1.90 \\
(1.36-2.65) \\
\end{array}$ & $<0.001$ & & $\begin{array}{c}1.90 \\
(1.36-2.65)\end{array}$ & $<0.001$ & & $\begin{array}{c}2.07 \\
(1.44-2.96)\end{array}$ & $<0.001$ & \\
\hline \multicolumn{10}{|c|}{ Market type; reference: dual-purpose } \\
\hline Wholesale & $\begin{array}{c}0.79 \\
(0.57-1.10)\end{array}$ & 0.161 & 0.042 & & & & $\begin{array}{c}0.79 \\
(0.571 .10)\end{array}$ & 0.161 & 0.042 \\
\hline Retail & $\begin{array}{c}0.69 \\
(0.51-0.92) \\
\end{array}$ & 0.012 & & & & & $\begin{array}{c}0.69 \\
(0.510 .93)\end{array}$ & 0.012 & \\
\hline $\begin{array}{l}\text { Species being sold } \\
\text { (reference: multiple } \\
\text { species)† }\end{array}$ & $\begin{array}{c}0.57 \\
(0.30-1.08)\end{array}$ & 0.084 & & & & & & & \\
\hline Electricity in facility & $\begin{array}{c}1.50 \\
(0.87-2.60)\end{array}$ & 0.148 & & & & & & & \\
\hline $\begin{array}{l}\text { Market sells poultry to } \\
\text { other vendors } \dagger\end{array}$ & $\begin{array}{c}1.21 \\
(0.92-1.58)\end{array}$ & 0.176 & & & & & & & \\
\hline $\begin{array}{l}\text { Weekly market closure } \\
(\geq 1 \text { day }) \dagger\end{array}$ & $\begin{array}{c}0.79 \\
(0.55-1.14)\end{array}$ & 0.207 & & & & & & & \\
\hline $\begin{array}{l}\text { Akaike information } \\
\text { criterion }\end{array}$ & & & & & 020.588 & & & 32.9017 & \\
\hline
\end{tabular}

*Blank cells indicate variables not included in model. RR, relative risk.

†Univariable results adjusted for month of sample collection and market work zones of sample collection. 

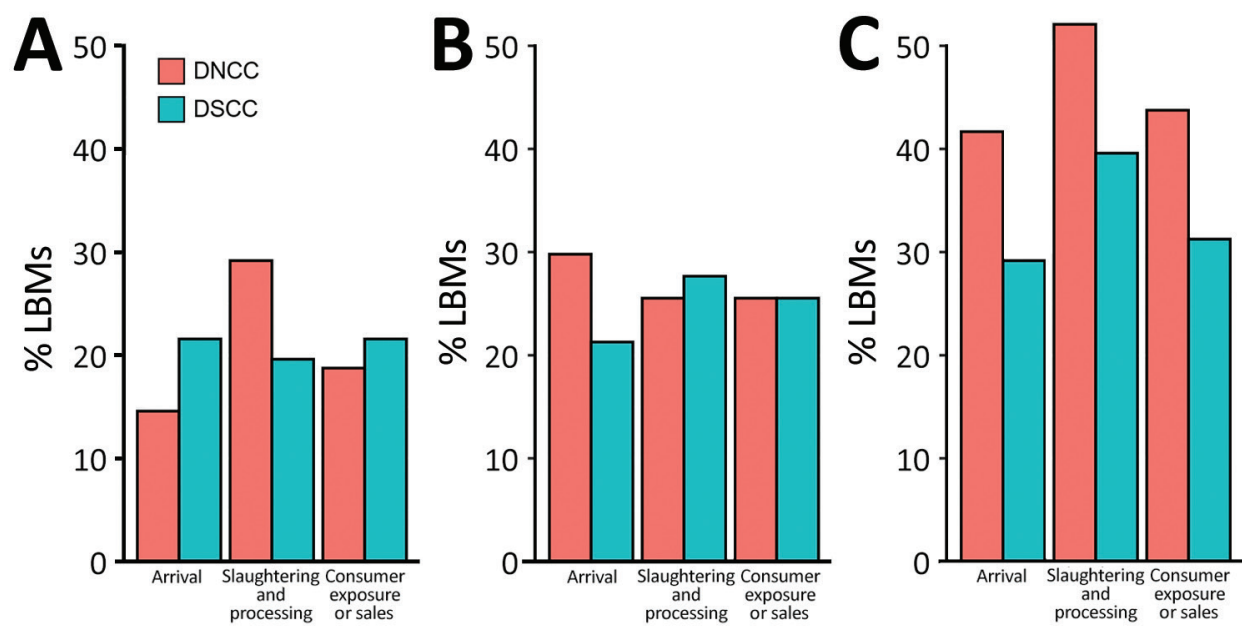

Figure 3. Distribution of influenza $\mathrm{A}(\mathrm{H} 5)$ virus environmental contamination in specific work zones in LBMs of DNCC and DSCC, Dhaka, Bangladesh, January-March 2016. A) January; B) February; C) March. DNCC, Dhaka North City Corporation; DSCC, Dhaka South City Corporation; LBM, live bird market. than retail-only markets (Appendix Table 3), which could promote virus introduction. Furthermore, our data suggest that the Sonali chicken crossbreed was dominant in dual-purpose markets compared with other markets (Appendix Table 3); this crossbreed has previously been shown to have a higher bird-level influenza $\mathrm{A}(\mathrm{H} 5)$ prevalence (11).

Our study revealed a significantly increased probability of influenza $\mathrm{A}(\mathrm{H} 5)$ environmental contamination in March in 3 of the 4 site-specific influenza $\mathrm{A}(\mathrm{H} 5)$ environmental contamination patterns. Our results also extend those from a recent study by demonstrating that, outside the month of March, the slaughter area was the environmental site most contaminated with influenza A(H5) in LBMs (25). Our findings suggest that to increase the probability of detection of influenza A(H5) environmental contamination, those conducting surveillance should consider the slaughtering and processing zone as the candidate sampling site within LBMs during the months leading up to the increased demand for poultry in April. Furthermore, our results suggest that market-level biosecurity characteristics did not influence the temporal variation in work zone-specific influenza $\mathrm{A}(\mathrm{H} 5)$ environmental contamination patterns (Appendix Figure 1).

Of note, only 1 market-level characteristic (market sells poultry to other traders) was reported to be marginally associated with the probability of S-only environmental contamination pattern. This relationship could be partly explained by the fact that LBM contamination level is not simply the result of continuous introductions of infected birds, but a consequence of virus recirculation and amplification within them (1). To further elucidate the market work zone-specific influenza A(H5) environmental contamination patterns identified in this study, follow- up studies into the social network of poultry trade in LBMs are needed to clarify the effect.

The first limitation of our study is that, although we triangulated information on Dhaka LBM characteristics from data collectors with that from market managers through telephone call data validation, the use of secondary data might have introduced undue reporting bias. Second, we focused our analyses on the 3-month period of the winter season (JanuaryMarch); further analyses should consider expanding the temporal scope of the investigation to better understand the seasonal trends identified in this study. Third, we used a sample pooling strategy (i.e., 18swab pools collected in $5 \mathrm{~mL}$ of viral transport medium), which has not been validated for the presence of serial dilution effect and should be evaluated in future studies. However, despite the 18-swab pooling, we found a significant positivity rate in pooled samples. Fourth, because of budgetary limitations, our study was only conducted in LBMs in the Dhaka metropolitan area without consideration of other cities in Bangladesh. Thus, caution should be taken in interpretation, because the environmental contamination of LBMs in Dhaka might not reflect the local idiosyncrasies of LBMs in other cities in Bangladesh. Finally, despite our efforts to address confounding effects, we could not consider other factors that could be associated with contamination levels, including the poultry trade network between LBMs and source farms and the presence of other infection reservoirs in LBMs.

In conclusion, this study demonstrates that LBMs located in DNCC of Dhaka are qualitatively more vulnerable to influenza $\mathrm{A}(\mathrm{H} 5)$ virus environmental contamination. The probability of influenza $\mathrm{A}(\mathrm{H} 5)$ environmental contamination is equally likely across all within-LBM sites investigated and particularly 
higher in the month of March. The slaughtering and processing zones of LBMs could serve as candidate zones for active surveillance programs. Future work also should evaluate the effects of poultry movement and LBM biosecurity in the epidemiology of influenza A (H5) virus. Sanitation practices, market closures, and slaughtering and processing practice interventions within LBMs would help to reduce market-level influenza A contamination.

\section{Acknowledgments}

We are thankful to the staff of the Department of Livestock Services (DLS), including the Central Disease Investigation Laboratory and Livestock Research Institute. We are also thankful to the Bangladesh Livestock Research Institute (BLRI) of the Bangladesh government, the Food and Agriculture Organization Emergency Centre for Transboundary Animal Diseases, Dhaka North City Corporation, and Dhaka South City Corporation for providing unrestricted support in sample collection, transportation, and the sample testing process.

Surveillance in live bird markets was funded by the United States Agency for International Development through the Food and Agriculture Organization Emergency Center for Transboundary Animal Diseases. The University of Queensland provided an international PhD scholarship (tuition fee offset and living stipend) to S.C.

\section{About the Author}

Dr. Chakma is a veterinary epidemiologist currently enrolled as a PhD Candidate at the UQ Spatial Epidemiology Laboratory, School of Veterinary Science, University of Queensland. He has expertise in epidemiological research, infectious diseases and AMR surveillance, and One Health issues.

\section{References}

1. Fournié G, Guitian FJ, Mangtani P, Ghani AC. Impact of the implementation of rest days in live bird markets on the dynamics of H5N1 highly pathogenic avian influenza. J R Soc Interface. 2011;8:1079-89. https:/ / doi.org/10.1098/ rsif.2010.0510

2. Henning J, Hesterberg UW, Zenal F, Schoonman L, Brum E, McGrane J. Risk factors for H5 avian influenza virus prevalence on urban live bird markets in Jakarta, Indonesia-evaluation of long-term environmental surveillance data. PLoS One. 2019;14:e0216984. https://doi.org/10.1371/journal.pone.0216984

3. Trock SC, Gaeta M, Gonzalez A, Pederson JC, Senne DA. Evaluation of routine depopulation, cleaning, and disinfection procedures in the live bird markets, New York. Avian Dis. 2008;52:160-2. https:// doi.org/10.1637/7980-040607-Reg

4. Garber L, Voelker L, Hill G, Rodriguez J. Description of live poultry markets in the United States and factors associated with repeated presence of H5/H7 low-pathogenicity avian influenza virus. Avian Dis. 2007;51(Suppl):417-20. https://doi.org/10.1637/7571-033106R.1

5. Bulaga LL, Garber L, Senne DA, Myers TJ, Good R, Wainwright $S$, et al. Epidemiologic and surveillance studies on avian influenza in live-bird markets in New York and New Jersey, 2001. Avian Dis. 2003;47(Suppl):996-1001. https:/ / doi.org/10.1637/0005-2086-47.s3.996

6. Kung NY, Morris RS, Perkins NR, Sims LD, Ellis TM, Bissett L, et al. Risk for infection with highly pathogenic influenza A virus (H5N1) in chickens, Hong Kong, 2002. Emerg Infect Dis. 2007;13:412-8. https:/ / doi.org/10.3201/ eid1303.060365

7. Wang X, Wang Q, Cheng W, Yu Z, Ling F, Mao H, et al. Risk factors for avian influenza virus contamination of live poultry markets in Zhejiang, China during the 2015-2016 human influenza season. Sci Rep. 2017;7:42722. https://doi.org/10.1038/srep42722

8. Tran DT, Hoang BT, Chanachai K, Prarakamawongsai T, Padungtod $\mathrm{P}$, Wongsathapornchai K, et al. Avian influenza outbreaks and surveillance in live bird markets, Quang Ninh Province, Vietnam, 2015-2017. Outbreak, Surveillance, Investigation \& Response (OSIR). Journal. 2018;11:1-7.

9. World Health Organization. Influenza at the human-animal interface: summary and assessment as of 5 March 2012. 2012 [cited 2019 Dec 3]. https://www.who.int/influenza/ human_animal_interface/Influenza_Summary_IRA_HA_ interface_05March12.pdf

10. Hill EM, House T, Dhingra MS, Kalpravidh W, Morzaria S, Osmani MG, et al. Modelling H5N1 in Bangladesh across spatial scales: Model complexity and zoonotic transmission risk. Epidemics. 2017;20:37-55. https://doi.org/10.1016/ j.epidem.2017.02.007

11. Kim Y, Biswas PK, Giasuddin M, Hasan M, Mahmud R, Chang YM, et al. Prevalence of avian influenza A (H5) and A (H9) viruses in live bird markets, Bangladesh. Emerg Infect Dis. 2018;24:2309-16. https:/ / doi.org/10.3201/ eid2412.180879

12. Khan SU, Gurley ES, Gerloff N, Rahman MZ, Simpson N, Rahman M, et al. Avian influenza surveillance in domestic waterfowl and environment of live bird markets in Bangladesh, 2007-2012. Sci Rep. 2018;8:9396. https:// doi.org/10.1038/s41598-018-27515-w

13. Gupta SD, Hoque MA, Fournié G, Henning J. Patterns of avian influenza A (H5) and A (H9) virus infection in backyard, commercial broiler and layer chicken farms in Bangladesh. Transbound Emerg Dis. 2021;68:137-51. https://doi.org/10.1111/tbed.13657

14. World Organisation for Animal Health. World animal health information database (WAHIS interface): quantitative data. 2020 [cited 2019 Jun 16]. https:/ / wahis.oie.int/\#/ dashboards/qd-dashboard

15. World Health Organization. Cumulative number of confirmed human cases of avian influenza $\mathrm{A}(\mathrm{H} 5 \mathrm{~N} 1)$ reported to WHO, 2003-2020 as of 10 July 2020. 2020 [cited 2020 Dec 20]. https://www.who.int/influenza/human_animal_ interface/2020_01_20_tableH5N1.pdf

16. Senne D, Pearson J, Panigrahy BJAD. Live poultry markets: a missing link in the epidemiology of avian influenza. Avian Dis. 2003;47:50-8.

17. Hood G, Roche X, Brioudes A, von Dobschuetz S, Fasina FO, Kalpravidh W, et al. A literature review of the use of environmental sampling in the surveillance of avian influenza viruses. Transbound Emerg Dis. 2021;68:110-26. https://doi.org/10.1111/tbed.13633

18. Rahman M, Mangtani P, Uyeki TM, Cardwell JM, Torremorell M, Islam A, et al. Evaluation of potential risk 
of transmission of avian influenza A viruses at live bird markets in response to unusual crow die-offs in Bangladesh. Influenza Other Respir Viruses. 2020;14:349-52.

https:/ /doi.org/10.1111/irv.12716

19. Chowdhury S, Azziz-Baumgartner E, Kile JC, Hoque MA, Rahman MZ, Hossain ME, et al. Association of biosecurity and hygiene practices with environmental contamination with influenza A viruses in live bird markets, Bangladesh. Emerg Infect Dis. 2020;26:2087-96. https:/ / doi.org/10.3201/ eid2609.191029

20. Yang G, Chowdury S, Hodges E, Rahman MZ, Jang Y, Hossain ME, et al. Detection of highly pathogenic avian influenza A(H5N6) viruses in waterfowl in Bangladesh. Virology. 2019;534:36-44. https://doi.org/10.1016/ j.virol.2019.05.011

21. Barman S, Turner JCM, Hasan MK, Akhtar S, El-Shesheny R, Franks J, et al. Continuing evolution of highly pathogenic H5N1 viruses in Bangladeshi live poultry markets. Emerg Microbes Infect. 2019;8:650-61. https:/ / doi.org/10.1080/ 22221751.2019.1605845

22. Biswas PK, Giasuddin M, Chowdhury P, Barua H, Debnath NC, Yamage M. Incidence of contamination of live bird markets in Bangladesh with influenza A virus and subtypes H5, H7 and H9. Transbound Emerg Dis. 2018;65:687-95. https:// doi.org/10.1111/tbed.12788

23. Turner JCM, Feeroz MM, Hasan MK, Akhtar S, Walker D, Seiler $\mathrm{P}$, et al. Insight into live bird markets of Bangladesh: an overview of the dynamics of transmission of H5N1 and H9N2 avian influenza viruses. Emerg Microbes Infect. 2017;6:e12. https://doi.org/10.1038/emi.2016.142

24. Sayeed MA, Smallwood C, Imam T, Mahmud R, Hasan RB, Hasan M, et al. Assessment of hygienic conditions of live bird markets on avian influenza in Chittagong metro, Bangladesh. Prev Vet Med. 2017;142:7-15. https://doi.org/ 10.1016/j.prevetmed.2017.04.009

25. Biswas PK, Giasuddin M, Nath BK, Islam MZ, Debnath NC, Yamage M. Biosecurity and circulation of influenza A (H5N1) virus in live-bird markets in Bangladesh, 2012. Transbound Emerg Dis. 2017;64:883-91. https:/ / doi.org/ 10.1111 /tbed.12454

26. Kang M, He J, Song T, Rutherford S, Wu J, Lin J, et al. Environmental sampling for avian influenza A (H7N9) in live-poultry markets in Guangdong, China. PLoS One. 2015;10:e0126335. https://doi.org/10.1371/ journal.pone.0126335

27. Indriani R, Samaan G, Gultom A, Loth L, Irianti S, Adjid R, et al. Environmental sampling for avian influenza virus $A$ (H5N1) in live-bird markets, Indonesia. Emerg Infect Dis. 2010;16:1889-95. https://doi.org/10.3201/eid1612.100402

28. Chen Z, Li K, Luo L, Lu E, Yuan J, Liu H, et al. Detection of avian influenza $\mathrm{A}(\mathrm{H} 7 \mathrm{~N} 9)$ virus from live poultry markets in Guangzhou, China: a surveillance report. PLoS One. 2014; 9:e107266. https://doi.org/10.1371/journal.pone.0107266

29. Cheng KL, Wu J, Shen WL, Wong AYL, Guo Q, Yu J, et al. Avian influenza virus detection rates in poultry and environment at live poultry markets, Guangdong, China. Emerg Infect Dis. 2020;26:591-5. https:/ / doi.org/10.3201/ eid2603.190888

30. Zhou X, Wang Y, Liu H, Guo F, Doi SA, Smith C, et al. Effectiveness of market-level biosecurity at reducing exposure of poultry and humans to avian influenza: a systematic review and meta-analysis. J Infect Dis. 2018;218:1861-75. https:/ / doi.org/10.1093/infdis/jiy400

31. Yuan J, Lau EH, Li K, Leung YH, Yang Z, Xie C, et al. Effect of live poultry market closure on avian influenza A (H7N9) virus activity in Guangzhou, China, 2014. Emerg
Infect Dis. 2015;21:1784-93. https:/ / doi.org/10.3201/ eid2110.150623

32. Kung NY, Guan Y, Perkins NR, Bissett L, Ellis T, Sims L, et al. The impact of a monthly rest day on avian influenza virus isolation rates in retail live poultry markets in Hong Kong. Avian Dis. 2003;47(Suppl):1037-41. https:/ / doi.org/ 10.1637/0005-2086-47.s3.1037

33. Swapan MSH, Zaman AU, Ahsan T, Ahmed F. Transforming urban dichotomies and challenges of South Asian megacities: rethinking sustainable growth of Dhaka, Bangladesh. Urban Sci. 2017;1:31. https:/ / doi.org/10.3390/urbansci1040031

34. Bangladesh Bureau of Statistics. District statistics. 2019 [cited 2021 Mar 25]. http:/ / www.bbs.gov.bd/site/ page/2888a55d-d686-4736-bad0-54b70462afda/-

35. Osmani M, Akwar H, Hasan Z, Chakma S, Hossain MM, Brum E. Sink surveillance, an innovative approach to identify HPAI and other emerging zoonotic pathogens in live bird markets in Bangladesh. Presented at: Prince Mahidol Award Conference (PMAC); 2018 Jan 29-Feb 3; Bangkok, Thailand.

36. Durand LO, Glew P, Gross D, Kasper M, Trock S, Kim IK, et al. Timing of influenza A(H5N1) in poultry and humans and seasonal influenza activity worldwide, 2004-2013. Emerg Infect Dis. 2015;21:202-8. https:/ / doi.org/10.3201/ eid2102.140877

37. Heine HG, Trinidad L, Selleck P, Lowther S. Rapid detection of highly pathogenic avian influenza H5N1 virus by TaqMan reverse transcriptase-polymerase chain reaction. Avian Dis. 2007;51(Suppl):370-2. https:/ / doi.org/10.1637/ 7587-040206R.1

38. Mohammed EA, Naugler C, Far BH. Emerging business intelligence framework for a clinical laboratory through big data analytics. In: Tran QN, Arabnia H, editors. Emerging trends in computational biology, bioinformatics, and systems biology. Boston: Morgan Kaufmann; 2015. p. 577-602.

39. Zhou X, Li Y, Wang Y, Edwards J, Guo F, Clements AC, et al. The role of live poultry movement and live bird market biosecurity in the epidemiology of influenza A (H7N9): A cross-sectional observational study in four eastern China provinces. J Infect. 2015;71:470-9. https:/ / doi.org/10.1016/ j.jinf.2015.06.012

40. Zhou X, Gao L, Wang Y, Li Y, Zhang Y, Shen C, et al. Geographical variation in the risk of H7N9 human infections in China: implications for risk-based surveillance. Sci Rep. 2020;10:10372. https:// doi.org/10.1038/ s41598-020-66359-1

41. Soares Magalhães RJ, Zhou X, Jia B, Guo F, Pfeiffer DU, Martin V. Live poultry trade in Southern China provinces and HPAIV H5N1 infection in humans and poultry: the role of Chinese New Year festivities. PLoS One. 2012;7:e49712. https://doi.org/10.1371/journal.pone.0049712

42. Delabouglise A, Choisy M, Phan TD, Antoine-Moussiaux N, Peyre M, Vu TD, et al. Economic factors influencing zoonotic disease dynamics: demand for poultry meat and seasonal transmission of avian influenza in Vietnam. Sci Rep. 2017;7:5905. https:/ / doi.org/10.1038/s41598017-06244-6

43. Van Kerkhove MD, Vong S, Guitian J, Holl D, Mangtani P, San S, et al. Poultry movement networks in Cambodia: implications for surveillance and control of highly pathogenic avian influenza (HPAI/H5N1). Vaccine. 2009; 27:6345-52. https://doi.org/10.1016/j.vaccine.2009.05.004

44. Moyen N, Ahmed G, Gupta S, Tenzin T, Khan R, Khan T, et al. A large-scale study of a poultry trading network in Bangladesh: implications for control and surveillance of 
avian influenza viruses. BMC Vet Res. 2018;14:12. https://doi.org/10.1186/s12917-018-1331-5

45. Sultana R, Nahar N, Rimi NA, Azad S, Islam MS, Gurley ES, et al. Backyard poultry raising in Bangladesh: a valued resource for the villagers and a setting for zoonotic transmission of avian influenza. A qualitative study. Rural Remote Health. 2012;12:1927.

46. Høg E, Fournié G, Hoque MA, Mahmud R, Pfeiffer DU,

Barnett $\mathrm{T}$. Competing biosecurity and risk rationalities in the Chittagong poultry commodity chain, Bangladesh. Biosocieties. 2019;14:368-92. https:/ / doi.org/10.1057/s41292-018-0131-2
47. icddr,b and United Nations Children's Fund. Evaluation of avian influenza communication for development initiativeimproving biosecurity in live bird markets: lessons learned report. Dhaka (Bangladesh); United Nations Children's Fund; 2013.

Address for correspondence: Shovon Chakma, School of Veterinary Science, Veterinary Science Building (8114), The University of Queensland, Gatton QLD 4343, Australia; email: shovon.chakma@uq.net.au

\section{January 2021}

\section{Waterborne Infections}

- Impact of Human Papillomavirus Vaccination, Rwanda and Bhutan

- Nosocomial Coronavirus Disease Outbreak Containment, Hanoi, Vietnam, March-April 2020

- Rising Ethnic Inequalities in Acute Rheumatic Fever and Rheumatic Heart Disease, New Zealand, 2000-2018

- Differential Yellow Fever Susceptibility in New World Nonhuman Primates, Comparison with Humans, and Implications for Surveillance

- Comparative Omics Analysis of Historic and Recent Isolates of Bordetella pertussis and Effects of Genome Rearrangements on Evolution

- Hospitalization for Invasive Pneumococcal Diseases in Young Children Before Use of 13-Valent Pneumococcal Conjugate

- Human Diversity of Killer Cell Immunoglobulin-Like Receptors and Human Leukocyte Antigen Class I Alleles and Ebola Virus Disease Outcomes

- Recency-Weighted Statistical Modeling Approach to Attribute Illnesses Caused by 4 Pathogens to Food Sources Using Outbreak Data, United States

- IgG Seroconversion and Pathophysiology in Severe Acute Respiratory Syndrome Coronavirus 2 Infection

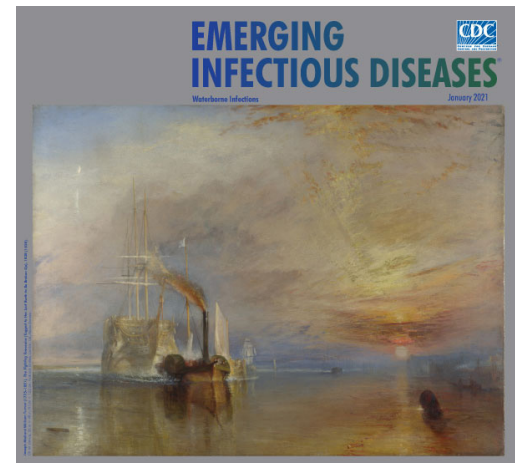

- Performance of Nucleic Acid Amplification Tests for Detection of Severe Acute Respiratory Syndrome Coronavirus 2 in Prospectively Pooled Specimens

- Susceptibility of Domestic Swine to Experimental Infection with Severe Acute Respiratory Syndrome Coronavirus 2

- Cellular Immunity in COVID-19 Convalescents with PCR-Confirmed Infection but with Undetectable SARS-CoV-2-Specific IgG

- Attribution of Illnesses Transmitted by Food and Water to Comprehensive Transmission Pathways Using Structured Expert Judgment, United States

- Viral Metagenomic Analysis of Cerebrospinal Fluid from Patients with Acute Central Nervous System Infections of Unknown Origin, Vietnam
- Invasive Fusariosis in Nonneutropenic Patients, Spain, 2000-2015

- Estimate of Burden and Direct Healthcare Cost of Infectious Waterborne Disease in the United States

- Intrafamilial Exposure to SARS-CoV-2 Associated with Cellular Immune Response without Seroconversion, France

- Post-13-Valent Pneumococcal Conjugate Vaccine Dynamics in Young Children of Serotypes Included in Candidate ExtendedSpectrum Conjugate Vaccines

- Precise Species Identification by Whole-Genome Sequencing of Enterobacter Bloodstream Infection

- Delineating and Analyzing Locality-Level Determinants of Cholera, Haiti

- Territorywide Study of Early Coronavirus Disease Outbreak, Hong Kong, China

- Prevalence of SARS-CoV-2, Verona, Italy, April-May 2020

- Coronavirus Disease among Workers in Food Processing, Food Manufacturing, and Agriculture Workplaces

- Estimating the Force of Infection for Dengue Virus Using Repeated Serosurveys, Ouagadougou, Burkina Faso 